\title{
Wannie Carstens: Profeet vir versoening - Sy enigste droom was om die Afrikaanse gemeenskap te versoen
}

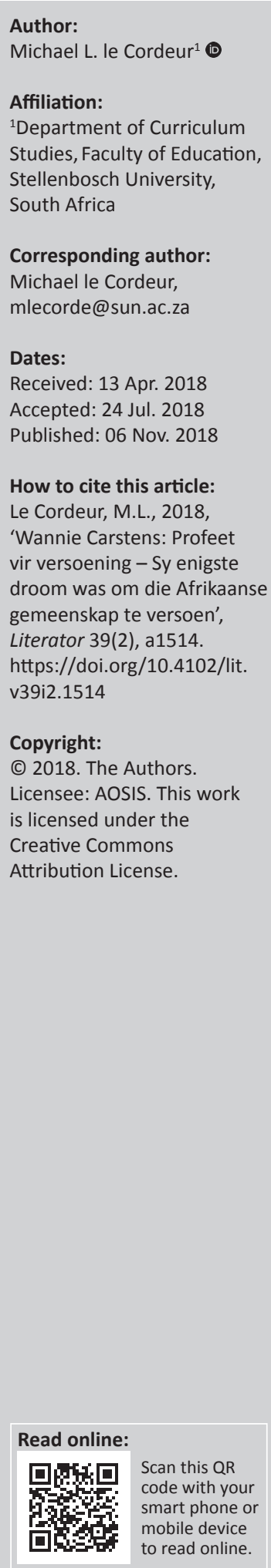

Wannie Carstens: An agent for reconciliation. His only dream was to reconcile the Afrikaans community. When I first met Wannie Carstens, I thought to myself: This must be one of those WOW moments that people talk about. Two individuals from different backgrounds came together, thanks to Afrikaans, and we clicked immediately. Since then, our friendship for the last 12 years has sustained a number of storms. But mostly our friendship bore fruit that would change the Afrikaans landscape irreversibly, whilst at the same time our friendship continues to grow. In this contribution I will firstly describe that WOW moment, after which I will elaborate on three aspects that glued our relationship together. First there was the establishment of the Afrikaanse Taalraad (ATR) (Afrikaans Language Council) which had started in 2003 already, became a reality in 2008 and lasted until 2013. It was in this time that we travelled to the Netherlands for the first time. Our relationship continued when we both served on the Board of the Suid-Afrikaanse Akademie vir Wetenskap en Kuns (SA Academy for Science and Arts). This journey, which was not always smooth for Wannie, lasted from 2012 till 2014. After Wannie completed his term as chairman of the Academy and my term as chair of the ATR came to an end, we again found a new common goal: that of a book called Ons kom van vêr (We came from afar). This will be the third aspect that I will be writing about in this contribution. Throughout this piece I will point out how Wannie has always strived towards reconciliation and how this theme runs through his life as a whole.

\section{Inleiding}

My ontmoeting met Wannie (Carstens) was een van daardie wow-oomblikke. Ons het dadelik gekliek (Cilliers 2011:3). Gesels 'n mens met die bebaarde, effens grys vriend van my (vir baie is hy net hulle proffie wat sedert 1991 by die Noordwes-Universiteit [NWU] doseer), is hy so gemoedelik soos die man langsaan. Oor Afrikaans en die werk wat die Afrikaanse Taalraad (ATR) doen, skryf Susan Cilliers (2011:3), is hy so opgewonde soos 'n kind oor Kersfees.

Aan die een kant is daar prof. Michael le Cordeur, dosent in Afrikaanse onderwys en voorsitter van die Departement Kurrikulumstudie aan die Universiteit Stellenbosch. Aan die ander kant is daar prof. Wannie Carstens. Hy het 'n lang en suksesvolle loopbaan gehad en was lank direkteur van die Skool vir Tale by die Noordwes-Universiteit se Potchefstroomkampus. Carstens was eers dosent in Taalkunde aan die Universiteit van Kaapstad nadat hy sy studie aan die Universiteit Stellenbosch voltooi het. Tydens sy lang loopbaan het hy verskeie akademiese publikasies die lig laat sien. Dit sluit in die ikoniese Norme vir Afrikaans (2018, daar was ook uitgawes in 1989, 1991, 1994, 2003, 2011) wat al vir dekades die 'handboek' van menige taalkunde-student in Suid-Afrika is, 'n lywige en goed nagevorste navorsingsboek (saam met prof. Kris van de Poel van Antwerpen), getiteld Teksredaksie (2012), en Ons kom van vêr (2016), 'n bundel waaroor ons saam as redakteurs opgetree het en waarin verskeie prominente bruin leiers hul standpunt oor Afrikaans verwoord. Sy mees onlangse pennevrug is Die storie van Afrikaans (2017) wat hy saam met prof. Edith Raidt geskryf het, en binnekort (2018) sal deel twee hiervan ook verskyn.

Dit was in Maart 2011 dat die digter Breyten Breytenbach voorspel het dat Afrikaans binnekort sou uitsterf omdat dit nie meer dieselfde amptelike status as tevore geniet nie en veg om oorlewing by universiteite. Prof. Wannie Carstens, toe die voorsitter van die ATR, en prof. Michael le Cordeur, toe nog doktor en ondervoorsitter van die ATR (hierna laat ek die titels weg), het egter ander planne gehad. Ons was allermins bereid om boedel oor te gee (Cilliers 2011:3). 
In daardie stadium was die ATR reeds in sy derde bestaansjaar en het dié raad reeds met sukses begin woeker om dié bedreigings te oorkom. Meer hieroor in die volgende afdeling. Agter 'n liggaam wat vandag 40 organisasies en 500000 mense verteenwoordig, was daar twee mans wat die droom van 'n versoende Afrikaanse taalgemeenskap gehad het: die een wit en die ander bruin. Wannie Carstens en Michael le Cordeur het as medestigterslede van die ATR na vore getree: Wannie die eerste voorsitter van 2008 tot 2011, en ek die eerste ondervoorsitter en later voorsitter van 2012 tot 2014. Met ons ywer en passie vir Afrikaans kon ons as twee goeie vriende tot dusver daarin slaag om die gevierde digter en voormalige politieke gevange verkeerd te bewys.

\section{Die Afrikaanse Taalraad Die Struggle en apartheid}

In haar artikel beskryf die Beeld-joernalis, Susan Cilliers (2011), die twee vriende se verskillende belewenisse van apartheid soos volg:

Vir Michael het apartheid onder andere beteken dat sy klere in die Struggle-jare letterlik in sy lyf in geslaan is, en sy ma dit uit die wonde moes trek. Prof Wannie Carstens se beperkte ervaring van apartheid was volgens hom dat hy weens Suid-Afrika se isolasie in die 70's nie as akademikus na Nederland kon gaan nie. Carstens het in die destydse SuidwesAfrika (nou Namibië) groot geword, grootliks onaangeraak deur segregasie, terwyl Le Cordeur as bruin jongeling in Wellington in die Wes-Kaap die lelikste momente daarvan beleef het. (bl. 3)

Dié omstandigheidskontraste is egter ' $n$ dun lagie vernis oor twee mans wat' $n$ diep liefde vir Afrikaans deel - 'n vuur wat in albei begin brand het danksy onderwysers soos mnre. Hennie Brand (in Suidwes) en Adam Small (in Wellington) wat die wonderlike wêreld van die Afrikaanse woord vir twee jong seuns oopgemaak het.

\section{Carstens (in Cilliers 2011) onthou apartheid so:}

Dit was 'n tyd van intense politieke woelinge. Die 1976-Sowetoopstand teen Afrikaanse onderrig het die persepsie oor Afrikaans as onderdrukkerstaal op die spits gedryf. Ironies genoeg het die UDF destyds ' $n$ stem vir die massas geword - in Afrikaans. (bl. 3)

Carstens het tot 'n belangrike besef gekom: 'Alle Afrikaanssprekendes praat dieselfde taal, dien dieselfde God en deel dieselfde drome vir hul kinders' (Cilliers 2011). Hy het ook tot die besef gekom dat politiek hulle uitmekaar skeur: 'Dit was duidelik dat die Afrikaanssprekende gemeenskap nie so kon aangaan nie. Dit het my droom geword om die Afrikaanse gemeenskap te help versoen', vertel hy aan Susan Cilliers.

Hierdie besef en die legio Afrikaanse organisasies wat op hul 'eie hopie koning gekraai het' (Cilliers 2011), was die motivering agter 'n gedagtegang wat veral sedert 2003 onder Carstens en taalliefhebbers begin posvat het.
Onder die vae benaming van die Nasionale Strategie vir Afrikaans het hy saam met dr Christa van Louw begin droom oor 'n liggaam wat die steun van álle Afrikaanssprekendes sou geniet en hulle sou kon versoen. Dié denkrigting het eindelik gelei tot die stigting van die Afrikaanse Taalraad in Mei 2008.

\section{Aanloop tot die stigting}

Die stigting van ' $n$ taalbelangeraad is gefundeer op die SuidAfrikaanse Grondwet (Republiek van Suid-Afrika [RSA] 1996) wat dit vir elke taal in die land moontlik maak om 'n taalbelangeraad vir elke taal te skep. Hoewel die raad eers in 2008 amptelik gestig is, lê die organisasie se eerste saadjies dekades terug, toe Carstens in die 80's dosent in Afrikaans by die Universiteit van Kaapstad was, waar hy hoofsaaklik vir bruin studente klas gegee het.

Die Federasie van Afrikaanse Kultuurvereniginge (FAK) het in September 2003 'n proses aan die gang gesit - op 'n seminaar getiteld 'n Groter voetspoor vir Afrikaans waartydens besluit is om die strewe na 'n verenigde en versoende Afrikaanse sprekersgemeenskap nuwe stukrag te gee. Die eerste taalberaad is in Augustus 2004 by die Paul Roos Gimnasium op Stellenbosch gehou (Nasionale Forum vir Afrikaans [NFA] 2004). Dié vergadering sal onthou word vir die robuuste debat tussen prof. Jonathan Jansen en dr Dan Roodt van die Pro-Afrikaanse Aksiegroep, of ProAfrikaans Action Group (PRAAG) toe Jansen vir Roodt van rassisme beskuldig het. Die tweede nasionale taalberaad is in Februarie 2007 in Pretoria gehou waar ek 'n pleidooi vir die stigting van 'n raad wat Afrikaanssprekendes kan verenig, gelewer het:

Daar moet wyd gekonsulteer word om die raad inklusief en verteenwoordigend te maak. Pogings moet veral aangewend word om ook Afrikaanssprekendes te betrek wat nie aan bestaande Afrikaanse organisasies behoort nie. Ons moet seker maak dat ons niemand uitsluit nie (Referaat by Nasionale Forum vir Afrikaans, 'Inklusiewe taalliggaam benodig', Pretoria, 16 Februarie 2007).

Die vergadering is opgevolg deur 'n byeenkoms op 14 April 2007 by die Universiteit Stellenbosch (US) onder die vaandel van die Nasionale Forum vir Afrikaans (NFA), die voorloper van die latere ATR, en is deur verteenwoordigers uit 'n breë spektrum van die Afrikaanse taal bygewoon, onder andere akademici van verskeie universiteite, taal en kultuurgroepe, asook prominente leiers op die Afrikaanse taalgebied. Die hoofdoel van die byeenkoms was om 'n strategie te formuleer vir die totstandkoming van 'n inklusiewe taalbelangeraad. Die gesprek is deur die destydse rektor van die US, prof. Russel Botman, geopen. In sy openingsrede het Botman, onder meer, genoem dat daar gestreef moet word om 'n plek te beding vir Afrikaans in die nasionale Apartheidsmuseum in Johannesburg sodat besoekers, en bepaald die nageslag, kan waarneem hoe die taal sy beeld verander het ná 1976: van die taal van die onderdrukker na 'n taal van bevryding en bemagtiging (Merton 2007:3). 
Wannie Carstens het veral drie redes aangevoer waarom 'n taalbelangeraad nodig was (Merton 2007:3):

Eerstens maak wetgewing voorsiening vir die stigting van 'n taalraad wat as statutêre liggaam na die belange van Afrikaans sou omsien. Tweedens is daar die groeiende gevoel dat Afrikaans gemarginaliseer word. Die derde belangrike rede is die voortsetting van die bemagtiging van agtergestelde Afrikaanse gemeenskappe deur die ontwikkeling van vaardighede deur Afrikaans.

Op my beurt het ek weer die inklusiwiteit van die voorgenoeme raad beklemtoon (Merton 2007:3):

Die stigting van 'n Afrikaanse taalbelangeraad sal slegs bestaansreg hê as hy al die sprekers van Afrikaans kan bemagtig terwyl dit ook tot voordeel van Suid-Afrika se ander inheemse tale behoort te wees.

Volgens my sou Afrikaans met die stigting van 'n taalbelangeraad die leiding neem sodat ander inheemse tale dit kon nadoen. Tydens 'n onderhoud met Millicent Merton (Die Burger, 16 April 2007:3) verwoord ek my gevoelens soos volg: 'Ons glo dat die sukses wat behaal sal word na die ander tale sal oorspoel.'

Verskeie ander sprekers het ook hul stem laat hoor. Ria Olivier, destyds bestuurslid van die Nasionale Taalliggaam vir Afrikaans (NTLA) en vandag projekbestuurder van die ATR, het in 'n terugblik op die voorafgaande proses sedert 2003 verwys op die versoening en vertroue tussen taalgenote wat voetjie vir voetjie ( $\mathrm{dr}$ Neville Alexander se woorde) bewerkstellig is. Die belang van sowel Afrikaans se bemagtigingsrol as sy hoër funksies is beklemtoon deur Christo van der Rheede, destyds uitvoerende hoof van die Stigting van Bemagtiging deur Afrikaans (SBA) en vandag die adjunkhoof van Agri Suid-Afrika.

Hy het voorts gesê:

... meer moet gedoen word vir die verstaan van die Afrikaanse
leefwêreld en daar moet rekening gehou word met sosiale
werklikhede (armoede versus rykdom, marginalisering), sosiale
herkonstruksie (die geskiedenis van die taal), sosiale identiteit
(stadigaan is 'n nuwe Afrikaanse identiteit besig om pos te vat)
en uiteindelik moet dit uitloop op sosiale bemagtiging (die bou
van openbare ondernemings rondom rolmodelle en helde). Val
ons vas in die verlede, kan ons nie aangaan na die toekoms.
(NTLA, 16 April 2007)

Prof. Danie Goosen, voorsitter van die FAK, het hom ook ten gunste van 'n taalraad uitgespreek; trouens hy was van mening dat daar 'n noodsaak daarvoor was. Hy sê voorts:

Apartheid oorlaai ons woorde en kleur ons toesprake in. Ons moet anderkant apartheid dink sonder om die verlede te ontken. Laat ons die historiese geleentheid aangryp om anderkant die verlede te beweeg en herdefinieer so die 'ons'. Taal is ' $n$ brug wat jouself by iets anders bring. Taal is die brug wat die gemeenskap herstel, en die sin vir onsself herontdek. (NTLA, 16 April 2007)

Die vergadering het eenparig besluit dat in beginsel die stigting van 'n taalbelangeraad in die vooruitsig gestel word.
Wannie Carstens het beklemtoon dat geen tydsraamwerk daaraan gekoppel is nie, maar die algemene gevoel onder die deelnemers was dat die tyd van praat verby is. Carstens (in Merton 2007:3) het dit só gestel: 'Ons wil dit so spoedig moontlik doen. Dis nou die era van dinge DOEN vir Afrikaans.'

Op my beurt het ek (in Merton 2007:3) soos volg gereageer: 'Die tyd was nog nooit so ryp as juis nou nie.'

Op 04 Augustus 2007 is daar ná bykans vier jaar se gesprekke, besinning en raadpleging tydens 'n NFA-byeenkoms geoordeel dat die tyd aangebreek het om aansoek te doen vir die registrasie van 'n liggaam wat sou instaan vir die belange van Afrikaans en om derhalwe gebruik te maak van die geleentheid wat gebied word ingevolge artikel 185 van die Grondwet (Republiek van Suid-Afrika [RSA] 1996). Hierdie proses is op versoek van die aanwesiges deur die Nasionale Forum vir Afrikaans (NFA) gefasiliteer.

Volgens prof. Jacques van der Elst is beplan dat die taalraad uiteindelik aansoek sou doen om akkreditasie by die Kommissie vir die Beskerming en Bevordering van die Regte van Kulturele, Godsdienstige en Linguistiese Gemeenskappe. In 'n landwye advertensie in die Afrikaanse media op 06 Augustus 2007, skryf Van der Elst as volg:

'Die te stigte Afrikaans belangeraad sal op 'n konstruktiewe manier na die ontwikkelings- en spesifieke behoeftes van al sy sprekers kan omsien en deur netwerking en samewerking doelgerig inhoud gee aan die ontwikkleing van 'n selfonderhoudende, geïntegreerde en waardetoevoegende Afrikaanse gemeenskap.' (Van der Elst 2007)

\section{Die stigting van die Afrikaanse Taalraad}

Na die verloop van 'n vyfjaarperiode waartydens daar hard gewerk is agter die skerms, het die Afrikaanse Taalraad (ATR) uiteindelik op Saterdag 24 Mei 2008 amptelik sy beslag gekry as 'n liggaam wat die Afrikaanse taalgemeenskap wou versoen en byeen wou bring. Dié geskiedkundige oomblik het afgespeel in die ewe historiese Goodnow-saal op Wellington, my tuisdorp. Wannie Carstens se idee van versoening is dus verwesenlik.

In die loop van vyf jaar is hierdie proses deur verskillende fases geneem en het dit via twee nasionale berade (Augustus 2004 te Stellenbosch en Februarie 2007 te Pretoria - dus geleenthede waartydens die leiers in die Afrikaanse gemeenskap betrek is by gesprekke en beplanning oor Afrikaans) en interimorganisasies (soos die Voortsettingskomitee en die NFA) en vele kleiner konsultasies en talle gesprekke tussen belanghebbende individue uiteindelik uitgeloop in die totstandkoming van die ATR.

In die loop van hierdie proses is drie oudits (bestekopnames almal goed gedokumenteer) gedoen om die stand van Afrikaans en die stand van die betrokkenheid van die Afrikaanse gemeenskap by Afrikaanse aktiwiteite en aksies te bepaal. Aan die hand van 'n wetenskaplik deurdagte en 
wyd gekonsulteerde taalplan, is die proses tot die vestiging van die ATR sorgvuldig bestuur. Soveel so dat die ATR se wordingsproses en legitimiteit as liggaam die steun geniet het van die Pan-Suid-Afrikaanse Taalraad (PanSAT) en die Kommissie vir die Beskerming en Bevordering van die Regte van Kulturele, Godsdienstige en Linguistiese Gemeenskappe (volgens Artikel 185).

Drie gassprekers het by die geleentheid opgetree.

Henry Jeffreys, toe nog Die Burger se redakteur, het die historiese belang daarvan uitgelig dat bruin en wit leiers die visie gehad het om saam 'n tree vorentoe te gee in die belang van Afrikaans (Brand 2008:4). Jeffreys het herhaal wat hy kort ná sy aanstelling as redakteur in sy toespraak by die Vriende van Afrikaans gesê het, naamlik:

'n Groot probleem in die taaldebat is dat byna geen sinvolle gesprek tussen die twee oorheersende komponente van die Afrikaanssprekende taalgemeenskap - die bruines en die wittes bestaan nie. 'n Goeie plek om te begin sou wees in die agtergestelde gemeenskappe. Dit is waar die twee komponente van die Afrikaanse taalgemeenskap mekaar kan vind en waar die grondslag gelê kan word vir 'n dinamiese en inklusiewe taalaksie. (Jeffreys 2016:360)

Die tweede gasspreker was dr Theuns Eloff, in daardie stadium die visekanselier van die Noordwes-Universiteit. Eloff maan (Referaat 'Sê sjibbolet' by die Stigting van die ATR, Wellington, 24 Mei 2008) dat die pad vorentoe nie maklik gaan wees nie. Eenheid tussen wit Afrikaanstaliges was reeds moeilik, wat nog te meer tussen wit en bruin en swart sprekers. Terwyl hy met sy vinger na my en Wannie gewys het, het hy voorts gesê:

Ek glo ons sal dit regkry as ons kan uitstyg bo rasse-karikature en veralgemenings. Ek glo die meeste Afrikaanstaliges wil hê dat die Taalraad moet slaag. Of Afrikaanstaliges hulle en hulle organisasies se aktiewe steun gaan gee, hang af van julle, die stigters. (T. Eloff [Afrikaanse Taalraad] pers. komm., 24 May 2008)

Dr Franklin Sonn, eertydse ambassadeur by die Verenigde Nasies (VN) en deesdae 'n sakeman, het daarop gewys dat Afrikaans ten beste in die toekoms slegs een taal tussen baie sal wees. Gevolglik pleit hy dat Afrikaanssprekendes hulle stem in die diversiteit eerder as net binne die Afrikaansgroepvorming moet laat hoor. Hy sê verder (Referaat tydens die stigting van die ATR, Wellington, 24 Mei 2008):

Ons het nou op 'n plek gekom dat ons hande vat en saam hoopvol die pad aandurf. Ons sien as'n eenheid die moontlikheid om saam te werk vir eenheid en die reg van Afrikaans om in eie reg volledig te herrys maar ook sy plek in te neem as taal van Afrika wat ook in 'n hoë mate vir 'n tweede keer die taal van opstand en protes en heropbou geword het. Afrikaans verdien om erkenning te geniet, nie net as taal van wetstoepassing, ontdoening en wegwysing nie, maar ook die taal wat eens op 'n tyd uit die massavergadersale van die Struggle opgeklink het. Die taal wat vandag wil insluit, koester, vredemaak en versoen. Afrikaans is in N.P. van Wyk Louw se woorde die magiese wat die Ooste verbind (geografies en polities) met die Weste hier aan die suidpunt van Afrika. Afrikaans moet soos Opperman dit stel, die Engel wees wat uit die klip herrys - die blom wat uit die baaierd opkom en ons land verryk en ons mense verenig. Afrikaans wil dan onteenseglik die handelsmerk Vervaardig in Suid-Afrika dra. Dit is die taal waarmee ek my vereenselwig. (F. Sonn, [Afrikaanse Taalraad] pers. komm., 24 May 2008)

Uiteindelik, na 'n lang proses wat op 13 September 2003 begin het, het die breë Afrikaanse taalgemeenskap die voorgestelde Akte van Oprigting eenparig aanvaar. Die ATR is met staande toejuiging begroet toe ek, wat op daardie stadium die vergadering gelei het, verklaar: 'Die Afrikaanse Taalraad is gestig' (Brand 2008:4).

Ongeveer 100 beraadgangers wat meer as 40 organisasies en 500000 mense verteenwoordig, het die byeenkoms bygewoon, die grotes en die kleineres, van die Noorde tot die Suide.

Prof. Wannie Carstens, in daardie stadium nog lid van die Pan-Suid-Afrikaanse Taalraad se NTLA, is as voorsitter verkies en ek is verkies tot ondervoorsitter met prof. Jacques van der Elst, toe nog die uitvoerende hoof van die SuidAfrikaanse Akademie vir Wetenskap en Kuns, as sekretaris en dr Danny Titus, uitvoerende direkteur van die Afrikaanse Taal- en Kultuurvereniging (ATKV) as die fondsbestuurder.

Die ander lede van die eerste direksie was: Alana Bailey, dr Gerrit Brand, dr Francois Bredenkamp, dr Louise Combrinck, Hennie de Wet, Ria Olivier, dr Karel Prinsloo, Hendrik Theys, prof. Piérre Theron en Christo van der Rheede.

$\mathrm{Na}$ afloop van die vergadering is 'n verklaring uitgereik waarin die bestuur van die ATR die organisasie verbind tot:

... 'n koördinerende, netwerkskeppende en inklusiewe liggaam waarvolgens Afrikaans die eiendom is van almal wat dit praat. Die ATR stel onder meer as doel om ook ander tale te bevorder en onderskryf meertaligheid. (Brand 2008:4)

\section{Logo en leuse}

Die kokerboom is as simbool vir die ATR se logo (Figuur 1) gekies omdat dit so 'n toonbeeld van oorlewing is. Dit is 'n vaalgroen plant met verrassende heldergeel blomme wat floreer in 'n dorre landstreek al is daar min hoop op oorlewing. Die boom benut die water deur dit in sy stam op te gaar. Pylen-boog-jagters het graag die sagte vogtige binnekant van stamme en takke van die boom uitgehol om as kokers vir hulle pyle te gebruik. Die kokerboom versinnebeeld die onstuitbare groei, uitreiking en voortgesette ontwikkeling van Afrikaans ten spyte van dikwels ongunstige omstandighede en die harde natuur van die politiek. Afrikaans blom heldergeel in sy letterkunde, sy spreektaal en op allerlei ander gebiede. Afrikaans bied sy taalgebruikers kokers vir hulle pyle om hom te bevorder en te verdedig. Daarom sou die ATR se nuusblad as Koker bekend staan (ATR 2008:4).

Ek en Carstens (Brand 2008) som dit soos volg op:

Die ATR is gestig as 'n geregistreerde, nie-winsgewende sambreelorganisasie wat Afrikaans wil bevorder deur met 


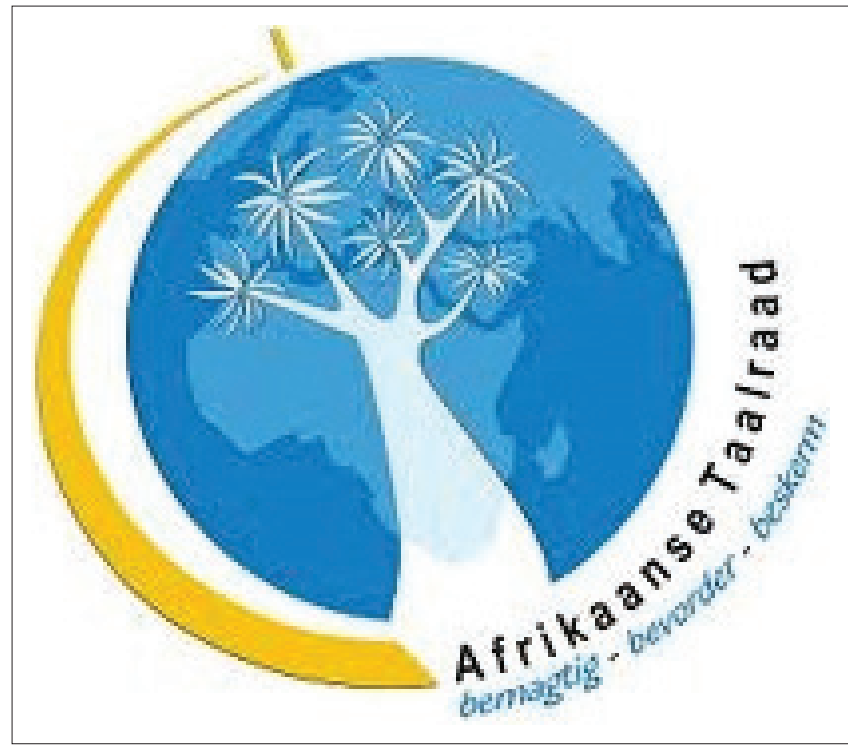

Source: Afrikaanse Taalraad (ATR), 2008, Bekendstellingsblad, besigtig n.d., vanaf http:// wwwafrikaansetaalraad.co.z

FIGUUR 1: Embleem en leuse van die Afrikaanse Taalraad.

ander Afrikaanse organisasies saam te werk en projekte aan te pak. Dit wil Afrikaanse taal en -taalgebruikers bemagtig en beskerm. (bl. 4)

Gevolglik het die eerste bestuur dit goedgedink om die volgende leuse vir die ATR te aanvaar: 'Bemagtig - bevorderbeskerm.'

\section{'n Droom bewaarheid}

Drie jaar later, tydens Carstens se uittrede as voorsitter by die tweede jaarvergadering waarna ek by hom sou oorneem, was Carstens oortuig die ATR is besig om die droom van ' $n$ versoende Afrikaanse taalgemeenskap te verwesenlik. Volgens Carstens het Afrikaanse organisasies mekaar se kundigheid spontaan begin gebruik danksy die onderlinge kontak bewerkstellig deur die ATR, byvoorbeeld met geletterdheidsontwikkeling, navorsing, befondsingskoördinering en gesamentlike uitvoer van projekte:

Elk van hierdie organisasies het voorheen op hul eie gewerk. Daar was gevolglik duplisering met byvoorbeeld die ontwikkeling van geletterdheidsmateriaal. Ons is besig om hierdie skanse af te breek. (Cilliers 2011:3)

\section{Doelwitte}

Die vraag is wat die ATR alles ten doel gehad het en wat sy vertrekpunte was. Hierdie aspekte word in besonderhede in die statuut uiteengesit (ATR 2009a:2). In sy eerste jaarverslag verduidelik Carstens (ATR 2009b:n.p.) hierdie doelwitte volledig. Opsommend sê hy:

Die ATR het die geleenthede wat die SA Grondwet en Art. 185 vir die ontwikkeling en bevordering van tale bied, benut om 'n belangeraad vir Afrikaans te registreer en te akkrediteer by PanSAT en die Kommissie vir die Bevordering en Beskerming van die Regte van Kultuur-, Godsdiens- en Taalgemeenskappe (wat op daardie stadium uiters gebrekkig funksioneer het). Die ATR het ten doel gehad om op 'n konstruktiewe manier na die ontwikkelings- en spesifieke behoeftes van al sy sprekers te kan omsien en deur netwerking en samewerking doelgerig inhoud te gee aan die ontwikkeling van 'n selfonderhoudende, geïntegreerde en waardetoevoegende gemeenskap. Die ATR, met Afrikaans en sy sprekers as primêre vertrekpunt, glo daar is plek vir Afrikaans in die nuwe Suid-Afrika, soos ook die geval is met die ander inheemse tale. Die ATR tree netwerkskeppend en koördinerend op sonder om die taak van geassosieerde organisasies oor te neem, maar so te koördineer dat die potensiaal van die organisasies in die beste belang van Afrikaans ontgin word. Die ATR wil deure vir Afrikaans by die regering oopmaak en sonder om konfronterend op te tree, 'n konstruktiewe bydrae maak tot die Suid-Afrikaanse gemeenskap.

\section{Suksesse}

In dieselfde jaarverslag gee Carstens (ATR 2009b:n.p.) 'n bondige uiteensetting van die grootste suksesse van die ATR tot op daardie stadium. Hy som dit só op:

Dit is waarskynlik die feit dat ons tot stand kon kom ten spyte van wat geassosieer is met Afrikaans se verlede. Die ATR se toewyding tot en 'n strewe na versoening asook 'n strewe na inklusiwiteit binne die totale Afrikaanse gemeenskap, het onderlinge vertroue op 'n persoonlike vlak onder die leiers geskep. Die ATR is dus die resultaat van 'n versoeningsproses, van 'n proses waar ons met mekaar gepraat het oor die verlede en hoe ons ten spyte daarvan steeds Afrikaans kan dien. Ons praat gereeld hieroor en ons hoop om in die afsienbare toekoms op 'n meer simboliese wyse gesamentlik as gemeenskap, ongeag ons verskeurde en verdelende verlede, vorentoe te gaan.

Terugskouend beskou ek vandag die ATR se bewusmakingsveldtog oor moedertaalonderrig as een van die grootste suksesse van die ATR. Hieroor laat Carstens hom soos volg uit:

Ons is besig om hierdie debat te wen. Navorsing het die waarde van moedertaalonderrig bewys. Taal is die kernmeganisme van leer. Indien jy jou moedertaal goed onder beheer het, bevorder kennis van daardie taalstrukture die aanleer van 'n tweede taal. (Cilliers 2011:3)

Die vraag kan ook gevra word waaraan kan die sukses toegeskryf word. Volgens Carstens:

$[h]$ et ons ... van die begin af besef dat ons stadig moet werk en dat ons as liggaam nie kan funksioneer sonder die steun van die totale Afrikaanse gemeenskap nie. Daarom volg ons dr Neville Alexander se raad (tydens die Eerste Nasionale Afrikaanse Taalberaad van Augustus 2004 op Stellenbosch): 'gaan voetjie vir voetjie vorentoe, en wees soms bereid om selfs 'n tree terug te

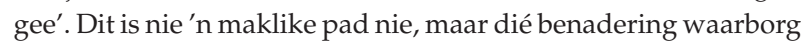
groter sukses op die langer termyn. (ATR 2009b:n.p.)

Kort ná die stigtingsbesluit in Wellington is die lede van die nuwe bestuur opdrag gegee om in die daaropvolgende jaar die ATR te vestig en in hierdie proses ook die grondwet van die ATR te finaliseer. Na slegs een jaar se werk kon die ATR die toekoms met vertroue aanpak. 


\section{Quo Vadis?}

Maar wat sou die toekoms inhou vir die ATR? In sy tweede jaarverslag beklemtoon Carstens (ATR 2010:n.p.) dat die werk nog ver van klaar is en dat werkers (organisasies, individue) nodig is: 'Ons vra werkers se tyd, energie, entoesiasme, geld, geduld en kundigheid.' Hy sê voorts:

Ons moet mekaar se netwerke deel en Afrikaanse organisasies wat nog nie betrokke is nie, betrek. Daar is steeds te min organisasies waarby bruin sprekers van Afrikaans betrokke is, by ons geaffilieer. Dit is 'n prioriteit wat dadelik reggestel moet word. Ons moet die onderlinge samewerking van Afrikaanse organisasies verder aanmoedig en selfs fasiliteer. Hoe kan die SA Akademie en organisasies soos die SBA verder saamwerk? Hoe kan die kundigheid van die Vereniging vir Regslui vir Afrikaans (VRA) ingespan word om die ATR by te staan in die howe? Hoe kan die strukture van die Dames Aktueel benut word om die SBA op grondvlak met geletterdheids- en bemagtigingsprojekte in die platteland te help? Ons moet die Afrikaanse taalgemeenskap mobiliseer rondom gesamentlike projekte, soos die Lees-om-teleer-projek wat ons tans dryf met die steun van die SBA, Vriende vir Afrikaans, die ATKV, die SA Akademie, die Taalmuseum, die Wes-Kaapse Taalkomitee en die Woordfeeskomitee van US. Ons moet mekaar se terreine respekteer. So beywer die ATR hom vir Afrikaans as taal, die SBA hom vir bemagtiging, Solidariteit hulle vir die regte van vakbondlede, die ATKV hom vir kultuurbevordering, en die SA Akademie vir Wetenskap en Kuns hom vir Afrikaans as hoëfunksietaal. Ons mag nie moedeloos word in die lig van soveel gebreke in SA nie. In die belang van AL die tale in die land glo die ATR dat ons 'n bydrae kan lewer tot die oplos van probleme in Suid-Afrika.

Wat die toekoms vir die ATR gaan inhou, sal slegs die tyd ons leer. Die tyd van en konteks waarin die ATR vandag funksioneer, is nou anders as in die begin en dit skep ook eie uitdagings. Die ATR se suksesse groei en die liggaam doen wat aan die begin beplan is: köordineer, bemagtig en beskerm Afrikaans.

\section{Die Hertzogprys aan Adam Small}

Die tweede aspek van my vriendskap met prof. Wannie Carstens waaroor ek hier skryf, is ons tyd saam by die SuidAfrikaanse Akademie vir Wetenskap en Kuns tydens Wannie se termyn as voorsitter en my deelname daaraan as raadslid. Dit was veral die toekenning van die Hertzogprys aan die digter en dramaturg, prof. Adam Small, in 2012, wat vir omstredenheid gesorg het.

In sy literatuurgeskiedenis beskryf J.C. Kannemeyer (1983:253) Small se drama Kanna hy kô hystoe, wat in 1965 verskyn het, as die belangrikste moderne werk deur 'n dramaturg in Suid-Afrika en André P. Brink (1974:152) sê reguit dat Kanna die belangrikste werk nóg in Afrikaans is. Maar ' $n$ groot onreg is Small aangedoen toe hy, anders as wat algemeen verwag is, nie in 1965 die Hertzogprys gewen het vir Kanna nie (Le Cordeur 2012a:13).

Toe Breyten Breytenbach in 2008 weer die Hertzogprys ontvang, het hy sy prys aan Small opgedra. Tydens sy aanvaardingstoespraak (waar ek teenwoordig was) het hy reguit gevra waar Adam Small se Hertzogprys is. Toe die Suid-Afrikaanse Akademie vir Wetenskap en Kuns (hierna slegs die SA Akademie) in 2009 'n eeufeesmedalje aan Small toegeken het, is dit gesien 'as 'n poging om sake reg te stel ... om te vergoed vir die feit dat hy al die jare tydens apartheid oor die hoof gesien is' (La Vita 2013:15).

Toe Carstens in 2011 die voorsitter van die SA Akademie word (en ek ook as raadslid verkies is), het hy versoening as sy vernaamste doelwit gestel. Op 'n vlug na Amsterdam die vorige jaar, het ek en Wannie begin praat oor die feit dat Adam Small in eie reg die Hertzogprys verdien, nie net weens sy voortreflikheid as skrywer nie, maar ook om regstelling te laat geskied. Om die Hertzogprys aan Small toe te ken, was dus iets wat Wannie baie na aan die hart gelê het. Dit was wel vir hom van groot belang dat die proses reg moes geskied. Hy was intens daarvan bewus dat die termyn van 'n Akademie-voorsitter slegs drie jaar lank is en dat daar dus min tyd was om reg aan Small te laat geskied.

Die besluit hiervoor sou egter nie by hom alleen lê nie. Hoogstens sou hy as die inisieerder van die regstellingsproses kon optree, want die finale besluit berus by die Raad van die Akademie. As voorsitter het hy die idee met die Akademie se hoofuitvoerende beampte gedeel en hom gevra om die saak met die Akademie se Letterkundekommissie op te neem. Soos die gebruik is met alle letterkundepryse wat die Akademie toeken, sou hierdie kommissie 'n aanbeveling moes maak. Na deeglike bespreking besluit die kommissie dat:

... daar vanjaar binne die reglement vir die Hertzogprys geen toekenning gemaak kan word nie. Aanbeveling ter oorweging: Dat die Raad dit oorweeg om vanjaar 'n oeuvretoekenning vir drama aan Adam Small te maak. (Van der Elst 2017:81)

Op 23 Maart 2012 het die Raad van die SA Akademie sonder hoofdelike stemming besluit om die Hertzogprys aan die 75-jarige Adam Small toe te ken (Die Suid-Afrikaanse Akademie vir Wetenskap en Kuns [SAAWK] 2012:2). Wannie het die vergadering vir'n wyle verdaag sodat hy en prof. Van der Elst 'n persverklaring kon voorberei. Die volgende woorde het daarna deur die land weerklink:

Die Raad van die Suid-Afrikaanse Akademie vir Wetenskap en Kuns het eenparig besluit om erkenning te verleen aan Adam Small, in wie se oeuvre sy drama Kanna hy kô hystoe kop en skouers uitstaan as 'n hoogtepunt in die Afrikaanse dramatiese kuns. (J. ven der Elst [Mediaverklaring deur die Suid-Afrikaanse Akademie vir Wetenskap en Kuns], pers. komm., 23 Maart 2012)

Soos verwag, het dit teenkanting ontlok en 'n hewige debat het ontstaan. Hier moet ek daarop wys dat dit nie die eerste keer was dat omstredenheid die Hertzogprys gekenmerk het nie. Van der Elst (2017:73) skryf dat die Hertzogprys sedert sy ontstaan 'n twisappel was. Hy verwys onder andere na die polemiek rondom die nietoekenning van die prys aan Uys Krige.

Alhoewel die toekenning van die Hertzogprys aan Small in 2012 uit verskeie oorde verwelkom is, is die SA Akademie 
kwalik geneem omdat hulle hul reglement geïgnoreer het. Aan die een kant is die Akademie geloof omdat dié liggaam uiteindelik die prys, wat Small reeds jare lank verdien het, aan hom toegeken het. Aan die ander kant het die Akademie sonder waarskuwing afgewyk van hul reglement wat bepaal dat die prys aan 'n drama toegeken moes word wat in die voorafgaande drie jaar verskyn het of 'n oeuvre wat met 'n drama uit dié tydperk verbind kan word.

Dit was veral die uitgewer, dr Nicol Stassen, wat van mening was dat dramas wat in die voorgeskrewe tydperk voor 2012 verskyn het, deur hierdie besluit benadeel is (April 2012).

In 'n brief op Litnet het ek 'n striemende aanval op Stassen gelewer waarin ek hom 'n 'pretbederwer' noem en onder meer gesê het:

... destyds was die dae van apartheid. Wel, ek sê dis nou die dae NA apartheid. En so lank ons leef en verstand het, moet ons die foute van die verlede regmaak. (Le Cordeur 2012b:2)

In sy repliek op Litnet, wys Stassen (2012) my daarop dat die Akademie nie sy eie reglement kan ignoreer net ter wille van 'n prys nie, al was dit ook hoe goed bedoel.

Die skrywer, Carolyn April, het met verskeie individue onderhoude gevoer hieroor. Ek haal enkeles hier onder aan uit haar artikel op Litnet wat op 03 April 2012 verskyn het:

André Brink, soos baie ander kenners, was dit eens dat die prys Small lankal toekom:

Vyftig jaar moes Adam Small wag om die Hertzogprys te kry vir Kanna hy kô hystoe, moontlik die beste drama in Afrikaans. Ná 'n halfeeu se wag is ' $n$ onreg uiteindelik reggestel, selfs al het dit dan gepaard gegaan met reglementêre kleitrappery en burokratiese omslagtigheid. (April 2012)

In haar kommentaar was die skrywer, Rachelle Greeff, ewe kwaai met Stassen:

Die uitgewer Nicol Stassen se brief aan die Akademie vir Wetenskap en Kuns oor die toekenning van die Hertzogprys aan Small sou in 'n ander land en 'n ander tyd 'n komedie kon wees. Stofoorloggie van die ooms, of iets in dier voege, sou mens dit al laggende kon noem (April 2012).

'n Groep hoofsaaklik bruin skrywers waaronder Willem Fransman jr., Peter Braaf, Floris Brown, Selvyn Milborrow, Elias P. Nel, Ria Olivier, Robert J. Pearce, Danny Titus, Edna van Harte, Barend van Vuuren, Daniel van Wyk en Anthony 'Speedo' Wilson, reageer ewe positief op Small se Hertzogprys deur hom op die webblad van Versindaba geluk te wens:

Ons, die ondergetekende digters, skrywers, dramaturge en belanghebbendes wil deur middel van hierdie verklaring ons opregte dank teenoor die Suid-Afrikaanse Akademie vir Wetenskap en Kuns uitspreek vir die toekenning van die Hertzogprys aan professor Adam Small. Vir ons was Small deur al die jare 'n simbool van verset, inspirasie en 'n ongevraagde mentor. Vir prof. Adam Small wil ons opreg gelukwens. Ons kan aan geen waardiger ontvanger van die prestigeprys dink nie! (Versindaba 2012:1)
Ook Small se boesemvriend en skrywer Abraham H. de Vries, was verheug toe hy die nuus meegedeel is dat die Hertzogprys aan Small toegeken is:

Ag, jy maak my nou baie bly. Adam Small moes lank terug die Hertzogprys vir Kanna gekry het. Hy's die een wat Kaaps (Kaapse Afrikaans) tot sy reg laat kom het. (Beeld, 23 Maart 2012)

Small kon weens swak gesondheid nie self die funksie bywoon nie, maar in sy dankwoord wat deur sy vrou, dr Rosalie Small, voorgelees is, doen hy spesiale moeite om 'n paar persone te bedank soos die SA Akademie onder Wannie se leierskap. Ek som sy brief op:

Ek betuig graag my waardering aan die huidige Suid-Afrikaanse Akademie vir Wetenskap en Kuns vir die Hertzogprys vir 2012, al kom dit feitlik op my sterfbed. My hoë waardering aan prof Jacques van der Elst vir al sy moeite asook die digters soos Willem Fransman Junior wat op my 75ste jaar vir my verse geskryf het. Spesiale dank aan prof Steward van Wyk en die Departement Afrikaans-Nederlands aan die Universiteit WesKaapland, asook prof. Michael le Cordeur, Jason Lloyd, Heinrich Wyngaard en Antjie Krog - mense wat aan die betekenis van my werk geglo het. (A. Small [Dankwoord by toekenning van die Hertzogprys] pers. komm., 12 September 2012)

Met die voordeel van agterna-kennis was Stassen se beswaar wel legitiem. Dalk het die emosie om Wannie in sy versoeningsdaad te steun en die jare lange strewe om aan Small te gee wat hom toekom, my oordeel beïnvloed. Ook André P. Brink, alhoewel in ekstase, was van mening dat die SA Akademie die saak beter kon hanteer het:

... ek is nie tevrede oor die manier waarop dit gebeur het nie. 'n Mens sou gehoop het dat die Suid-Afrikaanse Akademie vir Wetenskap en Kuns die bietjie moeite kon gedoen het om 'n klein aankondiging te publiseer om te sê dat die besondere reglement, waar die probleem gekom het, hersien of opgeskort is. Die Akademie kon ná 'n halfeeu van onreg, die woorde ('wat binne die afgelope drie jaar gepubliseer is') wat in elk geval nooit die daglig moes gesien het nie, geskrap het. (April 2012)

Maar die enorme voordeel wat Wannie Carstens se versiendheid as leier en inisieerder van die regstellingsproses vir ons gebring het, kan nie ontken word nie. 'n Jaar later, net voor sy terugkeer uit sy ballingskap van stilte, het Small in 'n onderhoud met Murray la Vita erken die Hertzogprys was 'n belangrike prikkel om hom uit sy ballingskap te laat terugkeer sodat hy nog 'n klein rukkie saam met ons wat hom so lief gehad het, kon wees (La Vita 2013:15).

Soos ek op Die Burger se Forumblad geskryf het: '[d]ie Hertzogprys eens so verdelend, het gesorg vir een van die groot versoeningsoomblikke; nie net van Wannie Carstens nie, maar van ons land' (Le Cordeur 2012a:13).

In sy dankwoord by die Hertzogprys beklemtoon Small juis dat die Hertzogprys danksy Carstens se visionêre optrede 'n simbool van versoening was. Ek haal Adam graag aan:

... die belangrikste gedagte vir vanaand moet wees: laat die tesamevoeging van die name Hertzog en Adam Small 'n groot simboliek van versoening vir die mense van ons land wees. 
Politieke versoening is belangrik, maar intellektuele versoening, wat slegs deur die filosofie en die kuns gedra kan word, is diepsinniger en die grond van alles. Laat ons opvrolik. In daardie ewige woorde: Kô lat ons sing! (Small 2012)

As ek vandag oor alles nadink, was dit, die kontroversie ten spyt, juis een van die oomblikke wat die band tussen my en Wannie onherroeplik sou verstewig en ons sou smee as broers.

\section{Dit kom van vêr}

Die derde en laaste aspek van my en Wannie se vriendskap waaroor ek in hierdie bydrae skryf, is ons boek Ons kom van vêr (Carstens \& Le Cordeur 2016).

Die storie van Afrikaans het in die verlede meestal gefokus op die taal se wit geskiedenis, terwyl die taal se bruin en swart geskiedenis misken is. In sy voorwoord skryf Carstens (2016:xiii) soos volg:

Dit was ons doel om die storie van Afrikaans vollediger te vertel as wat in die verlede die geval was toe meestal gefokus is op die wit geskiedenis. Dit was problematies, want die storie van Afrikaans het in die verlede die taal se bruin en swart geskiedenis misken.

Ek en Wannie was van mening dat om die storie meer volledig te vertel, ons ook die storie van die bruin sprekers van Afrikaans moes vertel. Ek verwoord my mening soos volg in die voorwoord waarin ek my aansluit by Carstens (Le Cordeur 2016b):

Daar heers tans 'n groot debat in Suid-Afrika oor die toekoms van Afrikaans ... In hierdie debat word daar dikwels vinger gewys na bruin mense en veral bruin leiers oor hul 'stilswye' in hierdie debat ... omdat bruin mense die grootste deel van die Afrikaanssprekende gemeenskap uitmaak. Omdat ek van mening is dat dit ' $n$ aanvegbare stelling is, het ek en prof. Wannie Carstens reeds aan die einde van 2015 besluit om 'n gedenkboek saam te stel opgedra aan prof. Adam Small met die oorspronklike tema: die bydrae van bruin sprekers van Afrikaans tot die ontwikkeling van Afrikaans as taal. Met hierdie boek wou ons aantoon dat bruin mense se verbintenis met Afrikaans inderdaad 'van vêr af' kom. (bl. xv)

In die proses word nie net bruinmense se bydrae tot die totstandkoming van Afrikaans geboekstaaf nie, maar die skrywers wys telkens met trots uit dat die bruin gemeenskap dikwels aan die voorpunt gestaan het in die stryd teen apartheid - en hulle het dit boonop trots in Afrikaans gedoen. (Worcester Standard 2017:13).

Ons het beplan om die boek op 21 Desember 2016 vry te stel, op prof. Small se 80 ste verjaarsdag. Prof. Small het sy seën op die projek geplaas. Hyself wou nie iets skryf nie, maar sy eggenote, dr Rosalie Small, het die inleidende hoofstuk geskryf, naamlik 'Wie is die poet?' (Small 2016:4-17)

Ons het verskeie skrywers uit hoofsaaklik die bruin gemeenskap genader om betrokke te raak en oor 'n aspek te skryf waarby hulle intens betrokke is/was en waar 'n bydrae tot Afrikaans gemaak is. Die respons het ons wildste drome oortref toe 34 skrywers, akademici en gemeenskapsleiers ingestem het om saam aan die boek te skryf. 'Op dié manier is verhale geboekstaaf wat andersins dalk nooit gepubliseer sou gewees het nie' (Paarl Post 2016:20).

Pakendorf (2017) is van mening dat ek en Wannie met hierdie boek 'n ryk aar raakgeboor het; en verder: 'Daar is kennelik 'n sterk behoefte om wat Carstens die "versweë stories" van bruin Afrikaanssprekendes noem (bl. xiv) te vertel.'

Die idee van die mooi storie word baie mooi verwoord deur een van die medeskrywers, Herman Bailey (in De Vries 2017:2), tydens die boekbekendstelling op Wellington:

Ek dink wat hierdie boek bereik het, is om ons stories in mooi Afrikaans te skryf, maar tog het dit'n stuk geskiedenis neergepen wat verlore sou gegaan het. En daarom dink ek dat hierdie die bereiking was van 'n baie, baie mooi ideaal. Ek het nooit aan my stuk as akademiese stuk gedink nie, maar dis goed dat dit op daardie vlak gebruik is.

Terselfdertyd was dit 'n geleentheid vir mense van die ou en nuwe Wellington om daadwerklik gesprek te voer oor toe én nou, oor hoe om mekaar te help anders maak, en Breyten Breytenbach se ideaal te verwesenlik (De Vries 2017).

Ongelukkig het die Hoër Hand ingegryp en prof. Small is van ons weggeneem op 24 Junie 2016. Hy sou nooit die produk sien nie, maar die skrywers - en Rosalie - het deur die bank gevoel dat ons moes voortgaan om sy nalatenskap te eer enersyds, en andersyds om die stigma dat bruin mense nie ' $n$ stem het oor Afrikaans of 'n bydrae te maak het tot Afrikaans nie, finaal te weerlê (Le Cordeur 2016a:11).

Ons het gevolglik besluit om die boek aan Adam Small op te dra. Op die flapteks van die boek verstrek ek die redes:

As akademikus, digter en dramaturg was Adam Small 'n stem vir die stemloses: het hy die brandende vraagstukke van 'n verdeelde Suid-Afrika op deurdagte dog onverskrokke wyse aangeroer. Sy invloed op die denke van sy mense is sigbaar in elke hoofstuk en elke tema in hierdie boek. Deur hierdie boek aan Adam Small op te dra, en dit op Versoeningsdag bekend te stel, gee gepaste erkenning aan 'n man wat lank in sy land misken is terwyl hy eintlik sy tyd vêr vooruit was.

Dr Franklin Sonn (Carstens \& Le Cordeur 2016) skryf op die agterblad van die boek:

Die gesprek oor Afrikaans en bruin mense wat die skrywers in hierdie boek aanroer, bring ook die verantwoordelikheid mee om minstens onder mekaar klaarheid te vind oor wat nou vorentoe met ons taal moet gebeur. Die boek is tydig in die opsig dat ná al die ambivalensie oor die Afrikaans van ons hart en die onverkwiklike manier waarop ons in hierdie taal verdruk en misken is, ons ons vryheid gekry het.

Die boek se publikasie het baie belangstelling ontlok en die skrywers het verskeie boekbekendstellings gehou, onder meer: op 16 Desember 2016 (Versoeningsdag) in Kaapstad; 
op 22 Februarie 2017 by die Graffitti-boekwinkel in Pretoria; op 24 Februarie by die Pniël-fees; op 18 Maart 2017 by die Breytenbach Sentrum in Wellington; op 25 Maart 2017 by die Protea Boekhuis in Stellenbosch, op 08 April 2017, by die Kleinplasie Museum in Worcester en tydens die BoekeJol op 17 Julie 2017 in Pretoria.

Tydens die eerste bekendstelling van die boek in die Kunstekaap-teater beklemtoon ek opnuut die versoeningsboodskap:

Ons bruin mense het iets te sê oor ons taal. Ons soek net die regte platform en ons wil nie ingeboks wees nie. Vandag is Afrikaans 'n taal van versoening. (Rapport 2016:9)

By die boekbekendstelling in Pretoria laat die hoofuitvoerende beampte van die SA Akademie, prof. Jacques van der Elst, hom soos volg uit oor die boek:

Ons kom van vêr is 'n boek van stemme, hoofsaaklik stemme uit die bruin gemeenskap, stemme van 'n wye verskeidenheid: van 'n skoonheidskoningin tot ' $n$ politikus, van digters en skrywers en burgemeesters en joernaliste, akademici, onderwysers, sportlui en sakelui. Die stemme klink nie eners nie - die variasie is net so groot soos die getal sprekers. En dit maak die boek aantreklik: sommige stemme wroeg, ander debatteer en argumenteer; die politiek praat naas die kultuur. Kortom: dis die moeite werd, ja seker belangrik, om in hierdie tydsgewrig van taalontwrigting kennis te neem van die kaleidoskoop menings wat in die boek voorkom. Ek dink die redakteurs, Wannie Carstens en Michael le Cordeur, het reeds daarin geslaag om met so baie skrywers 'n omvattende veld te dek. Ons kom van vêr is 'n noodsaaklike boek wat vir seker 'n opvolg verdien. (J. van der Elst [Voordrag by boekbekendstelling van Ons kom van vêr], pers. komm., 22 Februarie 2017)

By die boekbekendstelling in Stellenbosch het dit deurgeskemer dat die inspirasie vir die boek van twee kante gekom het. Eerstens: daar was die brandende begeerte om Small te vereer juis omdat hierdie profeet selde in sy eie land geëer is (Eikestadnuus 2017:13).

Tweedens: Dit was volgens Carstens (Pienaar-Brink 2017:16) moeilik om inligting te kry oor die bruin gemeenskap se bydrae tot die ontwikkeling van Afrikaans: 'Daar is heelwat gepubliseer oor die bruin gemeenskap as sodanig, maar die taalkant is verwaarloos, en meestal nie gedokumenteer nie. Dit is dan dat dinge problematies word.'

In 'n onderhoud met die Wellingtonse gemeenskapsblad Die Courant wy ek uit oor die waarde van die boek vir bruin mense:

Myns insiens is die boek se grootste waarde dat dit die stigma dat bruin mense nie ' $n$ stem het oor Afrikaans of ' $n$ bydrae te lewer het tot Afrikaans nie, weerlê. (Die Courant 2017:3)

In 'n artikel in Die Burger voer ek die argument verder:

In die proses word nie net bruin mense se bydrae tot die totstandkoming van Afrikaans geboekstaaf nie, maar die skrywers wys telkens uit dat die bruin gemeenskap dikwels aan die voorpunt gestaan het in die stryd teen apartheid - en hulle het dit trots in Afrikaans gedoen. Met hierdie boek slaag die skrywers daarin om veral bruin Afrikaanssprekendes se trots in hul taal te laat herleef! (Le Cordeur 2016a:11)

Die destydse voorsitter van die Akademie, prof. Wessel Pienaar, het tydens die eerste boekbekendstelling in 2016 gesê die boek kan 'n besonders kosbare dokument wees: 'Dit kon nie op 'n beter tyd gekom het nie' (Netwerk24 2016).

Elmari Rautenbach skryf op Die Burger se kunsblad (2017), dit is 'n:

... insiggewende bundel wat ontstaan het as 'n wens om die digter en dramaturg Adam Small op sy oudag te wys hoeveel bruin skrywers woelt hier om verandering. Small se onverwagse dood het redakteurs Michael le Cordeur en Wannie Carstens nie ondergekry nie. So groot was die momentum dat 36 verhale uiteindelik oor verskillende rolle wat bruin Afrikaanssprekendes in die Struggle gespeel het deur middel van Afrikaans. (bl. 10)

Die boek het ook internasionale erkenning gekry. Die Nederlandse taalkundige van die Universiteit van Nijmegen, prof. Pieter Muysken skryf in die Maandblad Zuid-Afrika soos volg:

Dit boek brengt die veelvormigheid van de taal en haar sprekers op een overtuigende manier in kaart, en laat zien hoe nauw taal en cultuur verweven kunnen zijn. De titel verwijst zowel naar de geografische diversiteit van de achtergronden van het Afrikaans als naar de bloei en het zelfbewustzijn van de bruine gemeenschap. (Muysken 2017:163)

Die laaste woord behoort aan 'n groot vriend van ons albei, prof. Christo van Rensburg, wat die grondverskuiwende boek So kry ons Afrikaans (2012) geskryf het in opdrag van ons (toe nog die voorsitter en ondervoorsitter van die ATR). Hy som ons boek soos volg op:

Die oorkoepelende narratief oor Afrikaans en sy mense het baie kante en baie vertellers. Die verhale in Ons kom van vêr vorm boublokke van belangrike momente vir 'n oorkoepelende geskiedenis van Afrikaans. Hierdie werk is ' $n$ besondere welkome bydrae wat vêr meer as een betekenis uitlig. By die redakteurs van die boek se oorspronklike doelwit kan lesers ook die volgende byvoeg: sodat ons meer van mekaar kan weet. (Van Rensburg 2017:1097)

Ter aansluiting by die oorheersende tema van hierdie artikel wil ek sê dat die skrywers in die boek bewys het dat Afrikaans nie net die taal van apartheid was nie. Diegene wat die boek lees, sal tot die slotsom kom Afrikaans ook die taal van die Struggle was en dit nou ook die taal van versoening is. In die woorde van prof. Van Rensburg (2017:1097): 'Die verhale van Ons kom van vêr sal die leser nog lank bybly. Moes hierdie boek nie al lankal verskyn het nie?'

\section{Ten slotte: Een groot Afrikaanse familie}

Carstens voel sterk dat die Afrikaanse gemeenskap reeds 'n groot bydrae gelewer het tot versoening en dit steeds kan doen. Ons kan nie bekostig om enigiemand uit te sluit nie, 
het ek hom telkemale hoor sê. Ons glo in mekaar en ons onderskeie geskiedkundige agtergronde en tradisies. Hy wys meer as een keer daarop dat baie swart mense verkies om Afrikaans as ' $n$ tweede taal by die skool- en werksplek en in navorsing te gebruik:

Alles is die resultaat van 'n lang proses van harde werk. Ons wil nie net praat oor samewerking nie, ons wil dit demonstreer en ' $n$ omwenteling in die Afrikaanse taalgemeenskap bewerk - dat mense ' $n$ versoende Afrikaanse gemeenskap sal nastreef. Dit sal egter net moontlik wees as die verskillende Afrikaanse groeperings mekaar werklik leer ken. Dit het reeds by die ATR gebeur. As ons mekaar ken, sal ons mekaar se vrese en drome verstaan. (Cilliers 2011:3)

Hy sluit sy 2009-jaarverslag af met die volgende woorde (let veral op hoe die tema van versoening soos 'n goue draad deur Wannie se denkprosesse loop):

Hoe raak hierdie stappe versoening vandag in Suid-Afrika, veral versoening tussen die wit en bruin sprekers van Afrikaans? Weer eens is die proses wat verloop moet word van groot belang: die luister met 'n oop gemoed, die aanhoor van slegte ervarings, die oopstel vir en die skep van kommunikasie tussen wit en bruin sprekers, die gelyke behandeling van mense (die menswaardigheid waarvan die Grondwet melding maak) en ook boetedoening deur bemagtigende optredes by die voorheen benadeeldes. Dit is al 'n stap in die regte rigting. Dit mag ook nie paternalisties wees nie, dit moet spreek van eerlikheid en opregtheid, van 'n erns om 'n verskil te wil maak. Dit is 'n lang en soms moeilike pad ...maar die Afrikaanse gemeenskap sal in sy totaliteit hierdie pad móét loop individueel sowel as groep. (ATR 2009b:n.p.)

Hy verwys in die onderhoud met Cilliers (Beeld 2011) na 'n baie persoonlike oomblik tussen die twee van ons as hy sê: Michael het in 'n persoonlike e-pos aan my die volgende gesê:

Aan die einde van die dag is ons almal in dieselfde bootjie, en ons sal mekaar moet help om daardie bootjie te maak roei, as ons die ander kant wil haal. (Le Cordeur 2012b)

Daarom is dit myns insiens gepas om ten slotte enkele van Carstens se juweeluitsprake te boekstaaf sodat dit eendag deur sy kleinkinders en hul kinders gelees kan word:

Ons wil die hele Afrikaanse familie verenig en Afrikaans so verruim dat ook tweedetaalsprekers daarby ingesluit is. (NFAbyeenkoms, 04 Augustus 2007).

Ons kan rou oor apartheid, of dit beter maak. (24 Mei 2008 by die stigting van die ATR)

Ons het geslaag om die verskeidenheid van Afrikaans onder een vaandel te verenig. (24 Mei 2008 by die stigting van die ATR)

Ons verwyd die beleweniswêreld van Afrikaans - van die Kaap tot in Limpopo, en tussen mense wat Afrikaans as eerste én tweede taal gebruik. (26 Augustus 2009, Algemene Jaarvergadering van die ATR)

Ons kan ook ander inheemse tale help bemagtig deur ons kundigheid oor byvoorbeeld taalstandaardisasie met hulle te deel. (26 Augustus 2009, eerste AJV van die ATR)
Afrikaans is ' $n$ inklusiewe instrument wat die vermoë het om te sorg dat mense vanuit verskillende kulture mekaar beter kan verstaan. Daarom moet ons nie skaam wees om Afrikaans juis oor kultuurgrense heen te gebruik en te bemark nie. (26 Augustus 2010, Tweede AJV van die ATR)

Afrikaans is een van Afrika se grootste prestasies. (12 September 2012, tydens oorhandiging van die Hertzogprys)

En hier eindig ek my verhaal, die verhaal oor 'n man wat 'n lang pad kom, wat in Europa die historiese penwortel van sy taal se oorsprong nagevors het, maar wat in Afrika die taal help ontwikkel het tot die juweel wat dit vandag is; wat deur hartseer en vreugde gegroei het tot die taalreus wat hy vandag is. Natuurlik was hy nie vlekkeloos nie, en hy sal ook die eerste een wees om dit te bevestig, maar altyd, ja altyd het hy geglo hierdie taal hét beslis 'n toekoms! En dat hierdie toekoms 'n inklusiewe fokus moet hê.

\section{Vereer met die Koker}

Die geskiedenis sal die rol van Wannie Carstens en sy rol in die bevordering en beskerming van Afrikaans beoordeel - hy het inderdaad 'n groot rol gespeel om Afrikaans as taal onder tale in Suid-Afrika in stand te hou en te laat groei. Soos 'n kokerboom versinnebeeld Wannie Carstens die onstuitbare groei, uitreiking en voortgesette ontwikkeling van Afrikaans ten spyte van dikwels ongunstige omstandighede en die harde natuur van die politiek.

Soos Adam Small, is Carstens ook 'n profeet wat nie in sy eie land geëer is nie. Toe die meeste van sy tydgenote nog regverdiging gesoek het vir apartheid, het hierdie profeet van versoening soos 'n kokerboom uitgestyg bó die res van sy portuurgroep.

Daarom was die KOKER-toekenning deur die ATR in November 2014 - die hoogste eer wat iemand in die Afrikaanse wêreld te beurt kan val - gepaste erkenning aan 'n man wat selde die nodige erkenning kry wat hom toekom (Cilliers 2014:4).

En daarom salueer ek hom. Wannie. My mentor, my vriend, my broer.

\section{Erkenning Mededingende belange}

Die outeur verklaar hiermee dat hy geen finansiële of persoonlike verbintenis het met enige party wat hom voordelig of nadelig kon beïnvloed het in die skryf van hierdie artikel nie.

\section{Literatuurverwysingslys}

Afrikaanse Taalraad (ATR), 2008, Bekendstellingsblad, besigtig n.d., vanaf http://www. afrikaansetaalraad.co.za

Afrikaanse Taalraad (ATR), 2009a, Akte van Oprigting, besigtig n.d., vanaf http://www. afrikaansetaalraad.co.za

Afrikaanse Taalraad (ATR), 2009b, Eerste Jaarverslag van die Afrikaanse Taalraad, Pretoria, op 26 Augustus 2009. 
Afrikaanse Taalraad (ATR), 2010, Tweede Jaarverslag van die Afrikaanse Taalraad, KunsteKaap, 26 Augustus 2010.

April, C., 2012, 'Adam Small aanvaar Hertzogprys terwyl debat uitkring', Books Live, besigtig 03 April 2018, vanaf http://bookslive.co.za/blog/2012/04/03/adamsmall-aanvaar-hertzogprys-terwyl-debat-uit/

Brand, G., 2008, 'Taalraad gestig in Wellington - Carstens tot voorsitter gekies', Die Burger, 26 Mei, 2008, bl. 4.

Brink, A.P., 1974, Aspekte van die nuwe drama, Kaapstad en Pretoria, Academica.

Carstens, W.A.M. \& Van de Poel, K., 2012 (hersiene uitg.), Teksredaksie, SUN Media, Stellenbosch.

Carstens, W.A.M., 2012, 'Toespraak by die oorhandiging van die Hertzogprys', Stellenbosch, 12 September

Carstens, W.A.M., 2016, 'Voorwoord' in Ons kom van vêr, Naledi, Kaapstad, bl. xiii.

Carstens, W.A.M. \& Le Cordeur, M.L.A. (Reds.), 2016, Ons kom van vêr: Bydraes oor bruin Afrikaanssprekendes se rol in die ontwikkeling van Afrikaans, Naledi, Kaapstad.

Carstens, W.A.M., 2018 (6de, hersiene uitgawe [ook uitgawes in 1989, 1991, 1994 2003, 2011]), Norme vir Afrikaans. Moderne Standaardafrikaans, J.L. van Schaik, Pretoria.

Carstens, W.A.M. \& Raidt, E.H., 2017, Die storie van Afrikaans, Uit Europa en van Afrika, Biografie van 'n taal, (Deel 1: Die Europese geskiedenis van Afrikaans), Protea Boekhuis, Pretoria.

Carstens, W.A.M. \& Raidt, E.H., 2018, Die storie van Afrikaans, Uit Europa en van Afrika. Biografie van ' $n$ taal, (Deel 2), Protea Boekhuis, Pretoria.

Cilliers, S., 2011, 'Een van daardie WOW-oomblikke: Afrikaanse organisasies deel nou hul kennis', Beeld, 03 Januarie, 2011, bl. 11.

Cilliers, S., 2014, 'Carstens erken vir taalstryd', Beeld, 14 November, 2014, bl. 4.

De Vries, W., 2017, 'Wellingtonse gemeenskapsleiers voer oop gesprek oor taal en identiteit', Litnet, besigtig op 23 Maart 2017, vanaf http://www.litnet.co.za/ wellingtonse-gemeenskapsleiers-voer-oop-gesprek-oor-taal-en-identiteit/

Die Courant, 2017, 'Ons is nou almal hiervandaan', 22 Maart, 2017, bl. 3.

Eikestadnuus, 2013, 'Akademici bespreek afkoms van Afrikaanse taal', 30 Maart, 2017, bl. 13, Protea-boekwinkel, Stellenbosch.

Jansen, J., 2016, 'Ons kom van vêr, sê bruinmense oor taal', Netwerk24, 18 Desember 2016, bl.1.

Jeffreys, H., 2016, 'In DF Malan se stoel', in W.A.M. Carstens \& M.L.A. Le Cordeur (Reds.), 2016, Ons kom van vêr, Naledi, Kaapstad.

Kannemeyer, J.C., 1983, Geskiedenis van die Afrikaanse Literatuur, Academica, Pretoria, Kaapstad en Johannesburg.

Le Cordeur, M.L.A., 2012a, 'Kô laat ons sing!', Die Burger, 27 September, 2012, bl. 13.

Le Cordeur, M.L.A., 2012b, 'Waarom kla oor Small se Hertzogprys?', Litnet, besigtig op 29 Maart 2018, vanaf http://www.litnet.co.za/waarom-kla-oor-adam-smallse-hertzogprys/
Le Cordeur, M.L.A., 2016a, 'Dit kom van vêr', Die Burger, 21 Desember, 2016, bl. 11. Le Cordeur, M.L.A., 2016b, 'Voorwoord' in Ons kom van vêr, Naledi, Kaapstad, bl. xv.

La Vita, M., 2013, 'Terug uit die land van stilte', Die Burger, 13 September, 2013, bl. 15.

Merton, M., 2007, 'Afrikaanse Taalraad moet ook ander dien', Die Burger, 16 April, 2007, bl. 3.

Muysken, P.,2017, 'Ons kom van vêr', in Maanblad Zuid Afrika, Jaargang 94, Nr.7, Augustus, bl. 163.

Nasionale Forum vir Afrikaans (NFA), 2004, 'Nule van eerste nasionale Afrikaanse Taalberaad', n.p., Stellenbosch, 04 Augustus.

Paarl Post, 2016, 'Die belangrikheid van Bruinmense in boek vasgelê', 15 Desember, 2016, bl. 20.

Pakendorf, G., 2017, Ons kom van vêr: 'n Litnet Akademies-resensie-essay, besigtig op 23 Maart 2018, vanaf http://www.litnet.co.za/ons-kom-van-ver-n-litnetakademies-resensie-essay/.

Pienaar-Brink, J., 2017, 'Almal se taal', Vrouekeur, 09 Junie, 2017, bl. 16.

Rautenbach, E., 2017, 'Talle titels op 2017-lys', Die Burger, 09 Januarie, 2017, bl. 10.

Republiek van Suid-Afrika (RSA), 1996, Die Grondwet van die Republiek van SuidAfrika. Nr. 108 van 1996, Staatsdrukker, Pretoria.

Die Suid-Afrikaanse Akademie vr Wetenskap en Kuns (SAAWK), 2012, 'Notule van die Jaarvergadering', n.p., Pretoria.

Small, A., 2012, Dankwoord by toekenning van die Hertzogprys (Voorgedra deur Dr Rosalie Small), 12 September.

Small, R., 2016, 'Wie is die Poet?', in W.A.M. Carstens \& M.L.A. Le Cordeur (Reds.), Ons kom van vêr, bl. 4-7, Naledi, Kaapstad.

Stassen, N., 2012, Repliek op Le Cordeur: Ignoreer reglemente vir die toekenning van pryse?, besigtig op 01 April 2018, vanaf https://www.litnet.co.za/repliek-dr-lecordeur-ignoreer-reglemente-vir-die-toekenning-van-pryse/

Stehle, R., 2012, 'Hertzogprys vir Adam Small', Beeld, 23 Maart, 2012, bl. 3.

Van de Poel, K., Linnegar, J. \& Carstens, W.AM., 2012, Text editing. A Handbook for students and practitioners, ASP, Antwerpen.

Van de Poel, K., Linnegar, J. \& Carstens, W.AM., 2017, EdiText. Making texts communicate effectively, Communication for Professionals, Antwerpen.

Van der Elst, J., 2007, 'Advertensie geplaas deur die SA Akademie vir Wetenskap en Kuns t.o.v die ter stigte Afrikaanse Taalraad', n.p., 06 Augustus.

Van der Elst, J., 2017, 'Adam Small en die Hertzogprys', in J. van der Elst (red.) Adam Small; Digter, denker, dramaturg: 'n Huldingingsbundel, bl. 73-88, Protea Boekhuis, Pretoria.

Van Rensburg, C., 2017, 'Oor mense, afstande en Afrikaans', Tydskrif vir Geesteswetenskappe 57(4), Desember, bl. 1093-1097.

Versindaba, 2012, Veels geluk prof Adam, besigtig op 31 Maart 2018, http:// versindaba.co.za/2012/03/31/verklaring-tov-hertzog-prys-aan-professor-adamsmall/

Worcester Standard, 2017, 'Afrikaans ook taal van versoening', 19 Januarie, 2017, bl. 13. 